\title{
Characteristics of ante- and postnatal risk factors of the food allergy in infants
}

\author{
SN Denisova ${ }^{1 *}$, MY Belitskaya ${ }^{1}$, TB Sentsova² ${ }^{2}$ VA Revyakina ${ }^{2}$, EV Pavlovskaya ${ }^{2}$, AA Trofimova ${ }^{1}$ \\ From Food Allergy and Anaphylaxis Meeting (FAAM 2013) \\ Nice, France. 7-9 February 2013
}

\section{Background}

Risk factors which promote the development of allergy to the cow milk protein in infants include antenatal sensitization, bottle feeding of neonates, early start of bottle or mixed feeding, postnatal sensitization of mite and pollen allergy. The aim of the study was to analyze a family history of the allergic diseases, course of pregnancy and delivery in mothers, effect of concomitant pathology on the development and course of food allergy in infants.

\section{Methods}

We examined 471 infants with food allergy and several degrees of the atopic dermatitis (AD). Moderate and severe $\mathrm{AD}$ were more common at the age of $0-12$ months old than at the age of $12-36$ months old $(80.9 \%$ and $55.6 \%$, respectively). In boys of the $12-36$ months old severe course of the disease was more common than in girls of the same age (14.6\% and $7.3 \%$, respectively). We used SCORAD index for estimation of AD severity.

\section{Results}

Positive family histories of the allergic diseases were revealed in $67.9 \%$ and $67.3 \%$ infants with moderate and severe course of $\mathrm{AD}$, respectively. In the half of these infants allergic diseases were found in the maternal line. Disturbances of the pregnancy and delivery in mothers of the infants with and without $\mathrm{AD}$ were equal; however these disturbances were more common in mothers of the infants with severe $\mathrm{AD}$. The postnatal risk factors of allergy were revealed in $11.7 \%$ of infants: prematurity (3.2\%), prenatal hypotrophy (4.7\%), intranatal asphyxia (2.3\%), cephalohaematoma (1.5\%).

${ }^{1}$ Russian National Research Medical University, Moscow, Russian Federation Full list of author information is available at the end of the article

\section{Conclusion}

The positive family history of allergy was high in all infants with $\mathrm{AD}$ independently on the age of the appearance of first signs of food allergy. Mothers with pathological course of pregnancy and delivery more often had infants with severe course of AD. Prevalence of the postnatal risk factors in healthy and ill infants was equal.

\section{Disclosure of interest}

None declared.

\section{Author details}

${ }^{1}$ Russian National Research Medical University, Moscow, Russian Federation. ${ }^{2}$ Research Institute of Nutrition, Russian Academy of Medical Sciences,

Moscow, Russian Federation.

Published: 25 July 2013

doi:10.1186/2045-7022-3-S3-P110

Cite this article as: Denisova et al:: Characteristics of ante- and postnatal risk factors of the food allergy in infants. Clinical and Translational Allergy 2013 3(Suppl 3):P110.

Submit your next manuscript to BioMed Central and take full advantage of:

- Convenient online submission

- Thorough peer review

- No space constraints or color figure charges

- Immediate publication on acceptance

- Inclusion in PubMed, CAS, Scopus and Google Scholar

- Research which is freely available for redistribution 